УДК 543.27.-8

\title{
ПІДВИЩЕННЯ ТОЧНОСТІ ВИМІРЮВАННЯ КОЕФІЦІЄНТА НАДЛИШКУ ПОВІТРЯ В КОТЛОАГРЕГАТАХ ІЗ ЗАСТОСУВАННЯМ ГАЗОАНАЛІЗАТОРІВ ЕЛЕКТРОХІМІЧНОГО ТИПУ
}

\author{
Бабак В.П. ${ }^{1}$, член-кореспондент НАН України, Запорожець А.О. ${ }^{1}$, Редько О.О. ${ }^{2}$ \\ ${ }^{1}$ Інститут технічної теплофізики НАН України, вул. Желябова, 2а, м. Київ, 03680, Україна \\ ${ }^{2}$ Національний авіаційний університет,просп. Комарова, 1, м. Київ, 03058, Україна
}

Розглянуто вплив метеорологічних параметрів на формування кількісного складу повітряного середовища та запропоновано спосіб підвищення точності вимірювання коефіцієнта надлишку повітря з врахуванням поточного значення концентрації кисню в повітрі.
Рассмотрено влияние метеорологических параметров на формирование количественного состава воздушной среды и предложен способ повышения точности измерения коэффициента избытка воздуха с учетом текущего значения концентрации кислорода в воздухе.
Considered the influence of meteorological parameters on the formation of the quantitative composition of air ambience. Proposed the method of improving accuracy the excess air ratio measuring taking into account the current value of oxygen concentration in the air.

Бібл. 13, табл. 3, рис. 9 .

Ключові слова: коефіцієнт надлишку повітря, газоаналізатори, димові гази, контроль, оптимізація, вимірювання, котлоагрегати.

$\left[\mathrm{O}_{2}\right]$ - поточна концентрація кисню в повітрі, \%;

$\left[\mathrm{O}_{2}\right]_{\text {вих. }}-$ об'ємна концентрація кисню у вихідних газах, \%;

$[\mathrm{CO}]_{\text {вих. }}$ - масова концентрація чадного газу у вихідних газах, мг/ $\mathrm{m}^{3}$;

$\left[\mathrm{CO}_{2}\right]_{\text {вих. }}$ - об'ємна концентрація вуглекислого газу у вихідних газах, \%;

$[\mathrm{NO}]_{\text {вих. }}$ - об'ємна концентрація монооксиду нітрогену у вихідних газах;

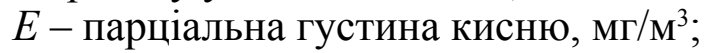

$e$ - парціальний тиск водяної пари, гПа;

\section{Bcmyn}

Процес горіння в значній мірі визначає надійність та економічність роботи котельного агрегату. Однією $з$ найважливіших задач в процесі експлуатації топки є регулювання процесу горіння, що забезпечує підтримку необхідної потужності та економічність роботи агрегату [1-4].

Зазвичай, головною характеристикою, що визначає економічність процесу горіння при спалюванні будь-яких видів палива в різних топкових пристроях, є коефіцієнт надлишку повітря (КНП, $\alpha)$. В процесі експлуатації при різних режимах формування необхідно підтримувати оптимальний КНП, при якому сума втрат
$\mathrm{M}_{\mathrm{O}_{2}}$ - молярна маса кисню;

$P-$ абсолютний тиск, гПа;

$P^{\prime}$ - абсолютний тиск, мм.рт.ст.;

$T$ - температура повітря, К;

$T^{\prime}$ - температура повітря, ${ }^{\circ} \mathrm{C}$;

$\alpha$ - коефіцієнт надлишку повітря;

$\varphi-$ відносна вологість повітря, \%;

ВЕР - вторинні енергетичні ресурси;

КНП - коефіцієнт надлишку повітря;

ГХ - градуювальна характеристика;

СКВ - середньоквадратичне відхилення.

теплоти з газами і від хімічної неповноти згорання є мінімальною.

Однак, слід не тільки підтримувати КНП, але й періодично перевіряти його значення. Визначення коефіцієнта надлишку повітря, як правило, здійснюють за складом продуктів згорання, зокрема залишковою концентрацією $\mathrm{O}_{2}$ у вихідних димових газах:

$\alpha=1+\frac{\left[\mathrm{O}_{2}\right]_{B u x}}{21-\left[\mathrm{O}_{2}\right]_{\text {Gux }}}$,

де $\left[\mathrm{O}_{2}\right]_{\text {вих }}$ - об’ємна концентрація кисню у вихідних димових газах. 
Для оперативного контролю якості процесу горіння можуть використовуватися газоаналізатори різних типів, принцип дії більшості 3 яких базується на формулі (1), що констатує об’ємну концентрацію кисню в навколишньому повітрі на рівні $21 \%$. Проте, в ряді робіт [1-4] зазначено, що даний рівень може змінюватися в залежності від ряду параметрів: температури, тиску та вологості повітря. Таким чином, розглянутий метод визначення КНП в газоаналізаторах містить вагому систематичну похибку.

Похибка характеризує недосконалість вимірювань (що зумовлено неточністю вимірювальних приладів, неповнотою наших знань про досліджуване явище, складністю врахування всіх побічних факторів, що впливають на вимірювання), а їх позитивною характеристикою $є$ точність. Точність це якість вимірювань, що відображає близькість їх результатів до дійсного значення вимірюваної величини. В метрології, як правило, точність характеризується побічно, через похибки вимірювання - вимірювання тим точніше, чим менша його похибка.

В даній роботі під підвищенням точності вимірювання КНП треба розуміти збільшення ступеню близькості оціненого шляхом непрямих вимірювань значення КНП з його дійсним (умовно істинним) значенням.

\section{Постановка завдання}

Мета роботи - розглянути існуючі методи та типові газоаналізатори для контролю за складом димових газів і запропонувати спосіб підвищення точності вимірювання КНП на основі поточної концентрації кисню в повітрі.

\section{Аналіз існуючих методів та приладів}

На даний час відомо ряд методів визначення газоподібних речовин у продуктах згорання котельних агрегатів. Вони розділяються на 3 категорії: фізичні, хімічні та фізико-хімічні (рис. 1).

Застосування механічних методів контролю газових сумішей, незважаючи на вибірковість, універсальність і простоту, є неприйнятним через невисоку точність, низьку чутливість та значний час тривалості аналізу. Діапазон застосування магнітних методів звужений до аналізу газів, що володіють парамагнітними властивостями (напр. $\mathrm{O}_{2}$, NO). Теплові методи аналізу характеризуються нелінійністю градуювальної характеристики, електричною залежністю коефіцієнта теплопровідності від навколишніх умов (температури газового середовища, коливання атфосферного тиску, швидкості газообміну і т.п.), великою інерційністю. Акустичні методи базуються на вимірюванні поглинання або швидкості розповсюдження звукових та ультразвукових хвиль у газовій суміші. Даний метод не $\epsilon$ вібірковим, і застосовується звичайно тільки для визначення $\mathrm{CH}_{4}, \mathrm{O}_{2}, \mathrm{H}_{2}$ в бінарних та псевдобінарних сумішах.

Таким чином, застосування класу фізичних методів $\epsilon$ недоцільним в газовому аналізі при визначенні широкого спектру речовин (особливо при малих концентраціях).

Визначення кількісних характеристик ваговим та об'ємним методами хімічного аналізу іноді викликає труднощі, головними 3 яких є:

- необхідність попереднього відділення аналіованої речовини від домішок;
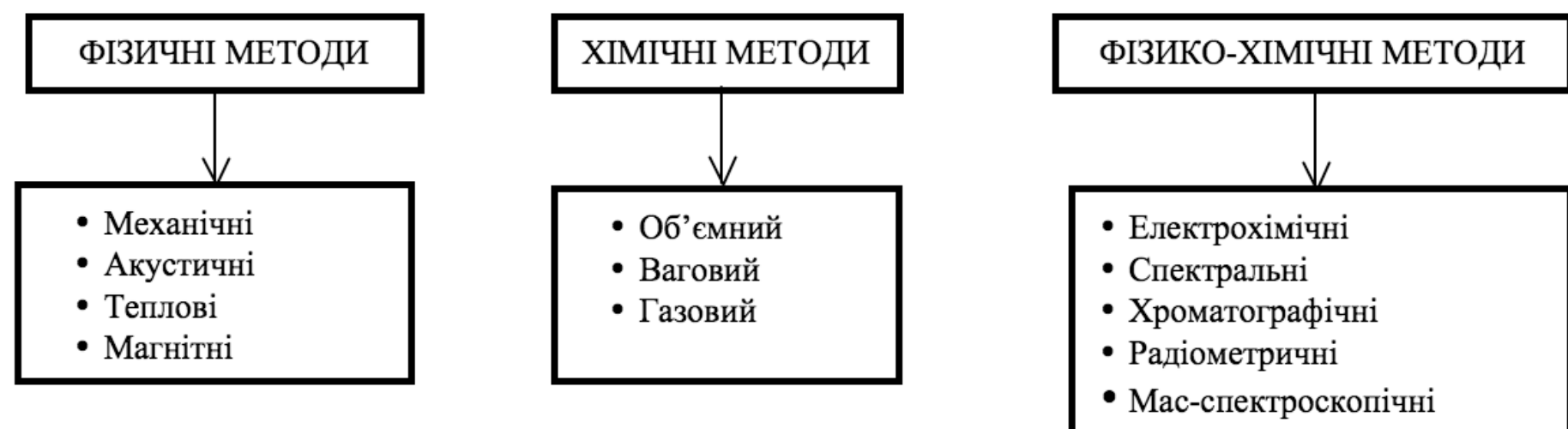

Рис. 1. Класифікація методів контролю складу газоподібних речовин. 
- недостатня чутливість, що обмежує визначення малих концентрацій аналізованих речовин;

- довга тривалість аналізу (особливо у ваговому методі).

Фізико-хімічні методи (рис. 2) відрізняються підвищеною чутливістю та вибірковістю, що дозволяє використовувати їх при визначенні досить малих концентрацій досліджуваних речовин. Серед переваг таких методів також $є$ відсутність необхідності застосування індикаторів, селективність та невеликий час аналізу проби.

Таким чином, фізико-хімічні методи відрізняються експресійністю, вибірковістю та високою чутливістю, що дозволило застосувати їх для визначення складу димових газів за допомогою газоаналізаторів.
Із великого числа електрохімічних методів аналізу газів на сьогоднішній день найбільш широко використовуються кондуктометричний, полярографічний, потенціометричний та кулонометричний.

Кондуктометричний метод аналізу газу базується на зміні електропровідності розчину внаслідок вибіркового поглинання ним конкретного елементу із контрольованої суміші. Під час аналізу (до і після поглинання відповідного елементу) проводиться вимірювання питомої електропровідності контрольованої суміші $\chi$.

Кондуктометричний аналіз характеризується необхідністю побудови градуювальної характеристики електропровідності розчину від концентрації в ньому досліджуваного газу.
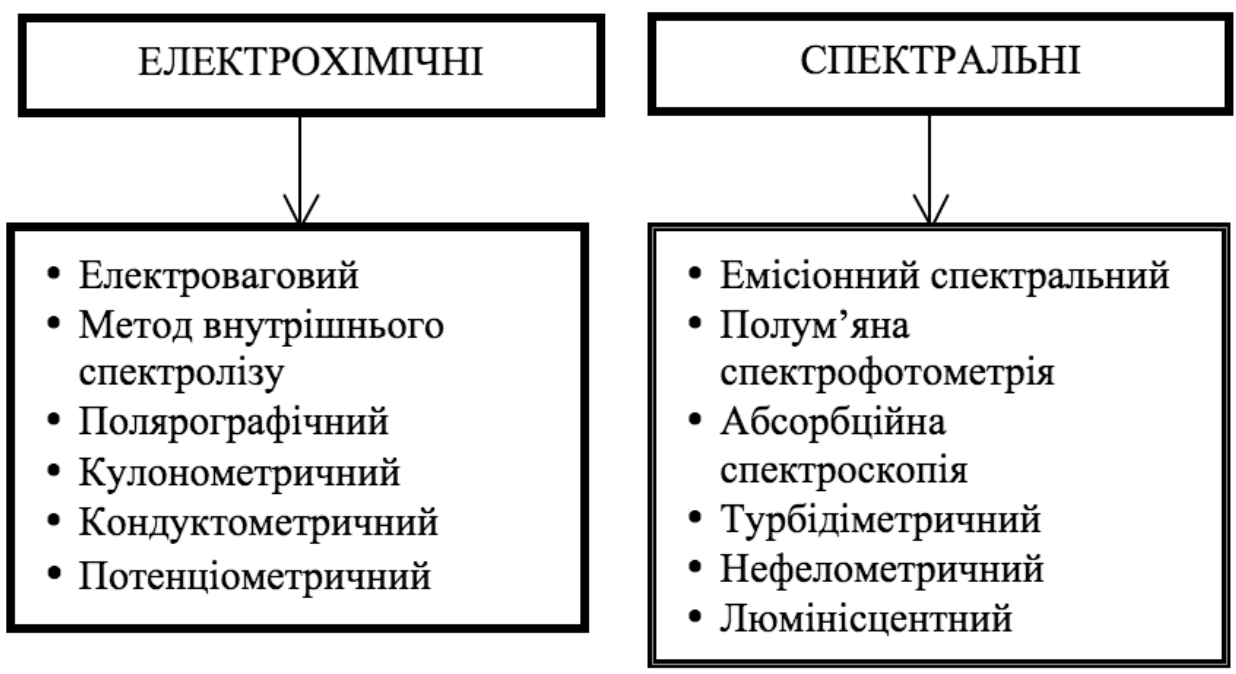

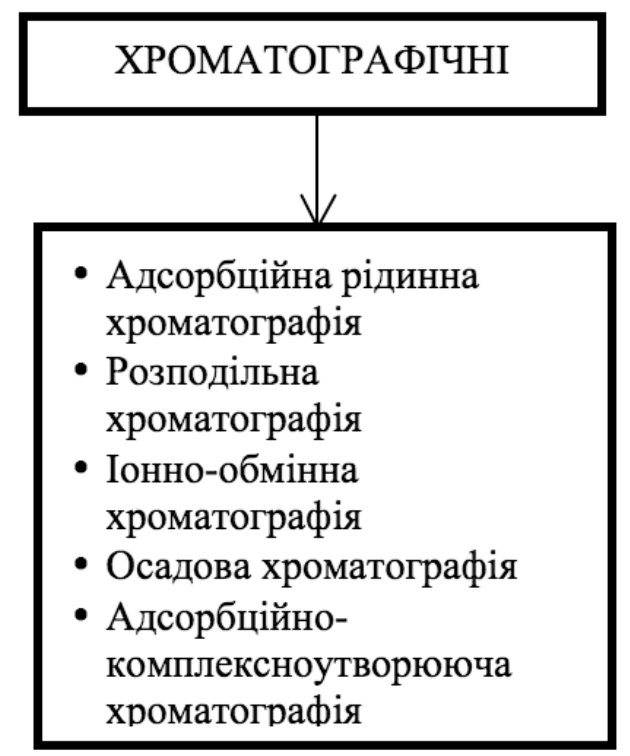

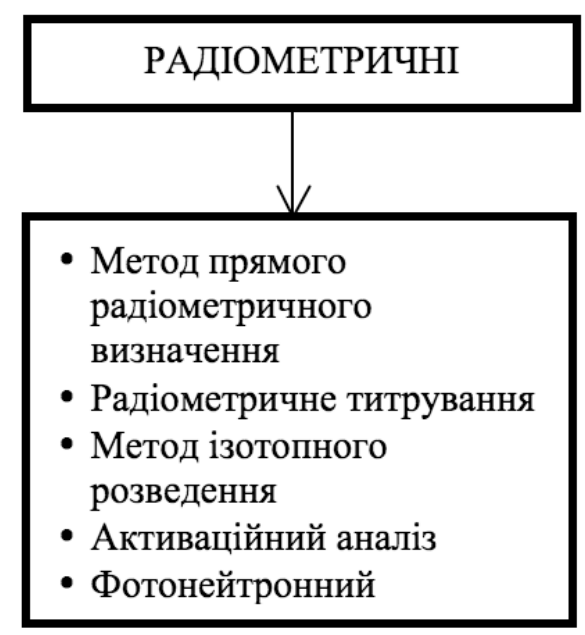

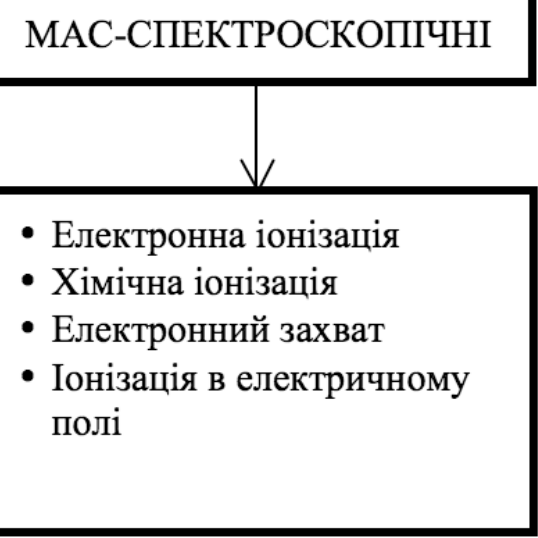

Рис. 2. Класифікація фізико-хімічних методів контролю складу газоподібних речовин. 
Залежність питомої електропровідності від температури визначається рівнянням:

$\chi(t)=\chi_{0} \cdot\left(1+A \cdot t+B \cdot t^{2}\right)$,

де $\chi_{0}$ - питома електропровідність розчину при $0{ }^{\circ} \mathrm{C} ; A, B$ - коефіцієнти, що залежать від природи електроліту та концентрації; $t$ - температура.

3 підвищенням температури електропровідність розчину збільшується, так як зменшення в'язкості розчину призводить до збільшення рухливості іонів. Підвищення ступеню дисоціації також $\epsilon$ причиною збільшення електропровідності. Підвищення температури на $1{ }^{\circ} \mathrm{C}$ призводить до збільшення електропровідності розчину на $2 \ldots 2,5 \%$.

Достатньо часто для аналізу газів використовують метод кондуктометричного титрування розчину аналізованої речовини. При цьому електропровідність вимірюють після додавання кожної дискретної порції титранта. Отриману залежність електропровідності розчину від кількості титранта наносять на графік - криву кондуктометричного титрування. Точка перегину кривої в координатах «електропровідність об'єм титранта» $є$ точкою еквівалентності.

Кондуктометричний метод аналізу є достатньо точним, швидким та об'єктивним. Відносна похибка визначення окремих електролітів цим методом складає $\pm 1 \%$, а при титруванні - не більше $\pm 2 \%$. Однак застосування методу обмежується тим, що електропровідність залежить від концентрації всіх наявних в розчині електролітів, що характеризує невисоку селективність кондуктометричного методу.

Точність визначення може бути збільшена, якщо електролітичну комірку помістити в термостат, а вимірювання зміни опору розчину проводити на кожній дискретній порції титранта після встановлення постійної температури.

Полярографічний метод базується на вимірюванні сили струму, що змінюється в залежності від напруги в процесі електролізу, в умовах, коли один електрод (катод) має достатньо малу площу поверхні, а інший (анод) навпаки більшу. Сила струму, при якому досягається повний розряд всіх іонів аналізованої речовини, що надходить до приелектродного простору внаслідок дифузії, називається граничним дифузійним струмом. Величина цього струму пропорційна вихідній концентрації досліджуваної речовини (іонів) в розчині.

Головною відмінністю полярографічного методу $\epsilon$ застосування індикаторного електроду в процесі електролізу. За рахунок малої площі поверхні густина струму на ньому стає порівняно великою. В результаті цього в частині розчину, що розташований поряд 3 таким електродом, концентрація відповідних іонів в процесі електролізу різко зменшується. Це призводить до швидкого встановлення рівноважного процесу, коли всі іони, що підходять до електроду за рахунок дифузії, розряджаються і сила струму встановлюється постійною (дифузійний струм).

Площа поверхні аноду є порівняно малою, тому поряд 3 електродом зміна концентрації іонів $є$ достатньо малою, що не впливає на криву залежності сили струму від прикладеної напруги.

Сила струму (при використанні ртутного крапельного електроду) в будь-який момент часу $t$ визначається рівнянням:

$I(t)=706 \cdot n \cdot D^{1 / 2} \cdot m^{2 / 3} \cdot t^{1 / 6} \cdot C$,

де $I(t)$ - сила струму, $n$ - кількість відновлювальних/окислювальних електронів, що вступили в реакцію з іоном, $D$ - коефіцієнт дифузії іона, $m$ - маса ртуті, що витікає 3 капіляра, $C$ - концентрація відновлювальних/окислювальних іонів.

Для одного типу іонів при однакових умовах величини $n, D, m, t \in$ постійними і сила струму прямо пропорційна концентрації відновлювального іона:

$I=K \cdot C$.

Ця залежність $\epsilon$ основою кількісного полярографічного аналізу: знаючи величину сили струму можна визначити концентрацію відновлювального іона.

На сьогоднішній день широкого розповсюдження набула полярографія на твердих електродах, що обумовлено рядом переваг даного методу: - робота в області позитивних потенціалів, де застосування ртутних крапельних електродів обмежено у зв'язку з анодним розчиненням ртуті;

- застосування загущених/твердих електролітів та підбору металу електрода у відповідності з особливостями визначення конкретного типу газу; 
• безперервний аналіз потоку контрольованої величини.

Сила струму на стаціонарному твердому електроді визначається рівнянням:

$I=F \cdot D \cdot S \cdot n \cdot \frac{C_{s}-C_{0}}{\delta}$,

де $F$ - число Фарадея, $D$ - коефіцієнт дифузії, $S$ - площа поверхні електроду; $n$ - число електронів, що прийняли участь в реакції, $C_{s}-$ молярна концентрація речовини у розчині, $C_{0}^{s}-$ молярна концентрація речовини біля поверхні електроду, $\delta$ - товщина дифузного шару.

Газоаналізатори, що працюють на основі полярографічних методів, застосовують для визначення газів, з окислювально-відновлювальними властивостями $\left(\mathrm{SO}_{2}, \mathrm{NO}_{2}, \mathrm{H}_{2} \mathrm{~S}, \mathrm{Cl}_{2}, \mathrm{O}_{2}, \mathrm{O}_{3}\right)$, при цьому точність класичної полярографії складає $\pm 2 \ldots 3 \%$. Також серед переваг методу вибірковість та висока чутливість.

Потенціометричний метод заснований на вимірюванні потенціалу індикаторного електрода, зануреного в аналізований розчин, що змінюється в результаті хімічних реакцій та залежить від температури та концентрації розчину. Потенціал індикаторного електроду вимірюється за допомогою порівняльного електрода. Під час вимірювання різниці потенціалів струм, що проходить через комірку, повинен мати достатньо невеликі значення (в діапазоні $10^{-6} \ldots 10^{-14} \mathrm{~A}$ ), щоб електроди не поляризувались.

Потенціали електрода, що відповідають окисно-відновній рівновазі, є функціями активності речовин, що беруть участь в процесі переносу електронів. Ці залежності описуються за допомогою рівняння (2).

Розрізняють пряму потенціометрію та потенціометричне титрування.

Перший метод допускає вимірювання абсолютного та точного значення електродного потенціалу, за допомогою якого можна встановити активність потенціального іона в розчині. Найбільш важливе значення даний метод має при визначенні активності іонів водню $\left(a_{H^{+}}\right)$, чи $\mathrm{pH}$ розчинів $\left(\mathrm{pH}=-\log a_{H^{+}}\right)$. Визначення активності інших потенційних іонів представляє широкий інтерес для розрахунку термодинамічних констант хімічної та електрохімічної рівноваги.

Розчинність більшості газів, таких як $\mathrm{SO}_{2}$,
$\mathrm{H}_{2} \mathrm{~S}, \mathrm{CO}_{2}$ та інших, невеликі їх концентрації в розбавлених розчинах електролітів дуже близькі до активностей, тому для визначення цих газів використовують прямий потенціометричний метод.

При потенціометричному титруванні в точці еквівалентності, коли концентрація досліджуваного газу стає незначною, різка зміна потенціалу індикаторного електроду свідчить про необхідність закінчення титрування. Метод потенціометричного титрування більш чутливий, та виключає суб'єктивну похибку, що виникає при візуальному знаходженні моменту завершення титрування.

Кулонометричний метод. Застосування даного методу аналізу засновано на повному електроокисленні чи електровідновленні електрохімічно активної досліджуваної речовини. При цьому фіксують загальну кількість струму, необхідної для електрохімічного перетворення досліджуваної речовини. По отриманим даним визначається кількість речовини, що піддалася перетворенню, та обчислюється пї концентрація.

В основу кулонометрії покладено закон Фарадея:

$m=\frac{M \cdot I \cdot t}{F \cdot n}$,

де $m$ - маса електрохімічно перетвореної речовини, $M$ - мольна маса досліджуваної речовини, $I$ - сила струму при електролізі, $t$ - час електролізу, $F$ - число Фарадея, $n$ - число електронів, що беруть участь в окислення/відновлення одного iона.

Для здійснення кулонометричного аналізу необхідно, щоб вихід по струму досліджуваної речовини становив $100 \%$, тобто весь струм, що протікає через комірку, має витрачатися на електрохімічну реакцію за участі досліджуваної речовини. Основною вимогою здійснення кулонометрії $\epsilon$ необхідність виключення побічних реакцій (хімічних та електрохімічних) за участі контрольованого зразка, інакше в результати аналізу буде внесена похибка.

В таблиці № 1 наведена порівняльна характеристика розглянутих методів при визначенні основних компонентів димових газів котельної установки та супутніх газів.

В результаті порівняння визначено, що найбільш інформативними методами при контролі 
Табл. 1. Порівняльна характеристика електрохімічних методів аналізу димових газів

\begin{tabular}{|l|c|c|c|c|}
\hline \multicolumn{1}{|c|}{ Газ } & $\begin{array}{c}\text { Кондуктомет- } \\
\text { ричний }\end{array}$ & Полярографічний & $\begin{array}{c}\text { Потенціо- } \\
\text { метричний }\end{array}$ & $\begin{array}{c}\text { Кулономет- } \\
\text { ричний }\end{array}$ \\
\hline Водень $\left(\mathrm{H}_{2}\right)$ & + & + & - & + \\
\hline Монооксид вуглецю $(\mathrm{CO})$ & + & + & - & + \\
\hline Діоксид вуглецю $\left(\mathrm{CO}_{2}\right)$ & + & - & - & + \\
\hline Вуглеводні $\left(\mathrm{C}_{x} \mathrm{H}_{y} \mathrm{O}_{z}\right)$ & + & + & + & - \\
\hline Оксиди азоту $\left(\mathrm{NO}_{x}\right)$ & - & + & - & + \\
\hline Кисень $\left(\mathrm{O}_{2}\right)$ & + & + & - & + \\
\hline Озон $\left(\mathrm{O}_{3}\right)$ & - & + & + & + \\
\hline Оксиди сульфуру $\left(\mathrm{SO}_{x}\right)$ & + & + & - & + \\
\hline Хлор $\left(\mathrm{Cl}_{2}\right)$ & + & - & + & + \\
\hline Фтор $\left(\mathrm{F}_{2}\right)$ & + & + & + & + \\
\hline
\end{tabular}

за складом димових газів котельної установки $є$ кондуктометричний та полярографічний методи (8 із 10 аналітичних параметрів). При цьому важливим $є$ їх симбіоз, оскільки кондуктометричний метод не дозволяє виміряти концентрацію $\mathrm{NO}_{x}$, а полярографічний $-\mathrm{CO}_{2}$. Врахування цих величин є необхідним фактором при режимноналагоджуваних роботах та комплексних екологічно-теплотехнічних випробувань котельних агрегатів.
Принцип дії електрохімічних газоаналізаторів заснований на залежності між параметрами електрохімічної системи та складом аналізованої суміші, що надходить до цієї системи. Серед недоліків таких приладів - низька селективність, обмежена швидкодія, недовговічність електрохімічного сенсора. Перевагами електрохімічних газоаналізаторів $\epsilon$ широка номенклатура контролюючих газів, можливість вимірювання наднизьких концентрацій досліджуваних

Табл. 2. Порівняльна характеристика сучасних портативних газоаналізаторів електрохімічного типу

\begin{tabular}{|c|c|c|c|c|c|}
\hline Тип & $\begin{array}{c}\text { Контрольовані } \\
\text { речовини }\end{array}$ & Особливості & $\begin{array}{c}\text { Час } \\
\text { підготовки } \\
\text { проби, с } \\
\end{array}$ & $\begin{array}{l}\text { Країна } \\
\text { виробник }\end{array}$ & $\begin{array}{l}\text { Ціна, } \\
\$\end{array}$ \\
\hline ПГА-300 & $\begin{array}{l}\mathrm{O}_{2}, \mathrm{CO}, \mathrm{H}_{2} \mathrm{~S} \\
\mathrm{NO}_{2}, \mathrm{NH}_{3} \\
\mathrm{SO}_{2}, \mathrm{H}_{2}\end{array}$ & $\begin{array}{l}\text { • можливість індивідуального } \\
\text { збирання приладу } \\
\text { • невеликі габарити } \\
\text { • вибухозахисна форма }\end{array}$ & 30 & Росія & $\begin{array}{l}\text { від } \\
933\end{array}$ \\
\hline МОНОЛИТ-2 & $\begin{array}{l}\mathrm{O}_{2}, \mathrm{CO}, \mathrm{NO} \\
\mathrm{NO}_{2}, \mathrm{SO}_{2} \\
\mathrm{NH}_{3}, \mathrm{H}_{2} \mathrm{~S}\end{array}$ & $\begin{array}{l}\text { • захист від вибуху } \\
\text { • розширений температурний } \\
\text { діапазон експлуатації } \\
\text { • сигналізація } \\
\text { • статистична обробка } \\
\text { результатів } \\
\text { • документування результатів } \\
\text { • пам'ять даних }\end{array}$ & - & Росія & $\begin{array}{c}\text { від } \\
1460\end{array}$ \\
\hline
\end{tabular}




\begin{tabular}{|c|c|c|c|c|c|}
\hline TESTO-330 & $\begin{array}{c}\mathrm{O}_{2}, \mathrm{CO}, \mathrm{H}_{2}, \\
\mathrm{NO}, \mathrm{NO}_{2}\end{array}$ & $\begin{array}{l}\text { - оснащений зондом пошуку } \\
\text { витоку } \\
\text { • пам'ять на } 200 \text { вимірювань } \\
\text { - USB-інтерфейс для } \\
\text { синхронізації з ПК }\end{array}$ & 60 & Німеччина & $\begin{array}{c}\text { від } \\
1290\end{array}$ \\
\hline TESTO-350 & $\begin{array}{c}\mathrm{O}_{2}, \mathrm{CO}, \mathrm{NO}, \\
\mathrm{NO}_{2}, \mathrm{SO}_{2}\end{array}$ & $\begin{array}{l}\text { • розширений температурний } \\
\text { діапазон експлуатації } \\
\text { • висока точність вимірювання } \\
\text { низьких концентрацій NO та } \\
\text { СО } \\
\text { • вбудований принтер }\end{array}$ & 60 & Німеччина & $\begin{array}{c}\text { від } \\
4760\end{array}$ \\
\hline OKA-T & $\begin{array}{c}\mathrm{CO}, \mathrm{H}_{2} \mathrm{~S}, \mathrm{SO}_{2} \\
\mathrm{NH}_{3}, \mathrm{NO}_{2}\end{array}$ & $\begin{array}{l}\text { • можливість одночасного } \\
\text { підключення до 4-х каналів } \\
\text { невеликі габарити та вага }\end{array}$ & 90 & Росія & - \\
\hline Полар-2 & $\begin{array}{c}\mathrm{O}_{2}, \mathrm{CO}, \mathrm{NO} \\
\mathrm{NO}_{2}, \mathrm{SO}_{2}, \mathrm{NH}_{3}\end{array}$ & $\begin{array}{l}\text { • пам’ять на } 990 \text { вимірювань } \\
\text { • вбудований принтер } \\
\text { • USB-інтерфейс для } \\
\text { синхронізації з ПК } \\
\text { - тривалість роботи без } \\
\text { підзярадки - до } 16 \text { год. }\end{array}$ & - & Росія & - \\
\hline АНКАТ-7361 & $\begin{aligned} \mathrm{NO}_{2}, & \mathrm{NH}_{3}, \mathrm{CO} \\
\mathrm{Cl}_{2}, & \mathrm{SO}_{2}, \mathrm{O}_{2} \\
& \mathrm{H}_{2} \mathrm{~S}\end{aligned}$ & $\begin{array}{l}\text { • тривалість роботи без } \\
\text { підзярадки - до } 34 \text { год. } \\
\text { • невеликі габарити та вага }\end{array}$ & 180 & Росія & $\begin{array}{l}\text { від } \\
370\end{array}$ \\
\hline
\end{tabular}

газів, порівняно низька ціна. В таблиці 2 приведено аналіз сучасних портативних газоаналізаторів, що використовуються для визначення якісного та кількісного складу димових газів.

Кліматичні характеристики середовища. Повітря - це природна суміш газів, що на $98 . .$.
99 \% складається 3 азоту і кисню, а також вуглекислого газу, води, водню, інертних газів та ін. (табл. 3). В промисловості та побуті повітряний кисень використовується в процесах згорання палива, при цьому його концентрація є одним 3 найважливіших параметрів при оптимізації про-

Табл. 3. Склад повітря

\begin{tabular}{|l|c|c|c|}
\hline \multicolumn{1}{|c|}{ Компонент } & Позначення & Об'ємна концентрація, \% & Масова концентрація, \% \\
\hline Азот & $\mathrm{N}_{2}$ & 78,084 & 75,50 \\
\hline Кисень & $\mathrm{O}_{2}$ & 20,948 & 23,15 \\
\hline Аргон & $\mathrm{Ar}$ & 0,934 & 1,29 \\
\hline Вуглекислий газ & $\mathrm{CO}_{2}$ & $31,4 \times 10^{-3}$ & $4,6 \times 10^{-2}$ \\
\hline Неон & $\mathrm{Ne}_{4}$ & $18,18 \times 10^{-4}$ & $1,4 \times 10^{-3}$ \\
\hline Метан & $\mathrm{CH}_{4}$ & $2 \times 10^{-4}$ & $7,4 \times 10^{-5}$ \\
\hline Гелій & $\mathrm{He}$ & $5,24 \times 10^{-4}$ & $3 \times 10^{-5}$ \\
\hline Криптон & $\mathrm{Kr}$ & $1,14 \times 10^{-4}$ & $8 \times 10^{-5}$ \\
\hline Водень & $\mathrm{H}_{2}$ & $5 \times 10^{-5}$ & $4 \times 10^{-5}$ \\
\hline Ксенон & $\mathrm{Xe}$ & $8,7 \times 10^{-6}$ & \\
\hline
\end{tabular}


цесу горіння.

Традиційно при розрахунку КНП рівень об'ємної концентрації кисню в повітрі складає $21 \%$. Проте багаторічні кліматофізіологічні дослідження дозволили не тільки спростувати твердження про стабільність концентрації кисню на рівнинах, але й запропонувати новий параметр кисню, що входить до складу повітря - парціальну густину кисню. В роботі [5] описується визначений парадокс, що полягає в помилковості трактування закону Дальтона: постійність процентного співвідношення газів повітря сприй- мається за постійність абсолютної кількості газів повітря, в тому числі і кисню.

В результаті цих досліджень встановлено зміну парціальної густини кисню в повітрі на рівнинах. Вона полягає в тому, що при добовій (сезонній) динаміці та коливаннях основних метеорологічних характеристик (температури, абсолютної вологості повітря, абсолютного атмосферного тиску), обумовлених динамікою атмосферних процесів, відбувається перерозподіл у часі і просторі парціальної густини кисню в повітрі, що проявляється в добовій (сезонній)

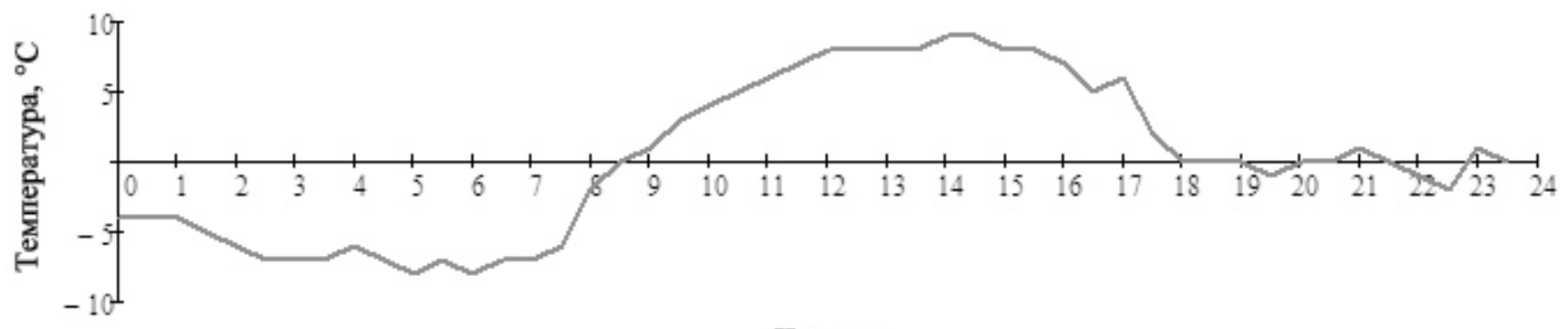

Час, год.

a)

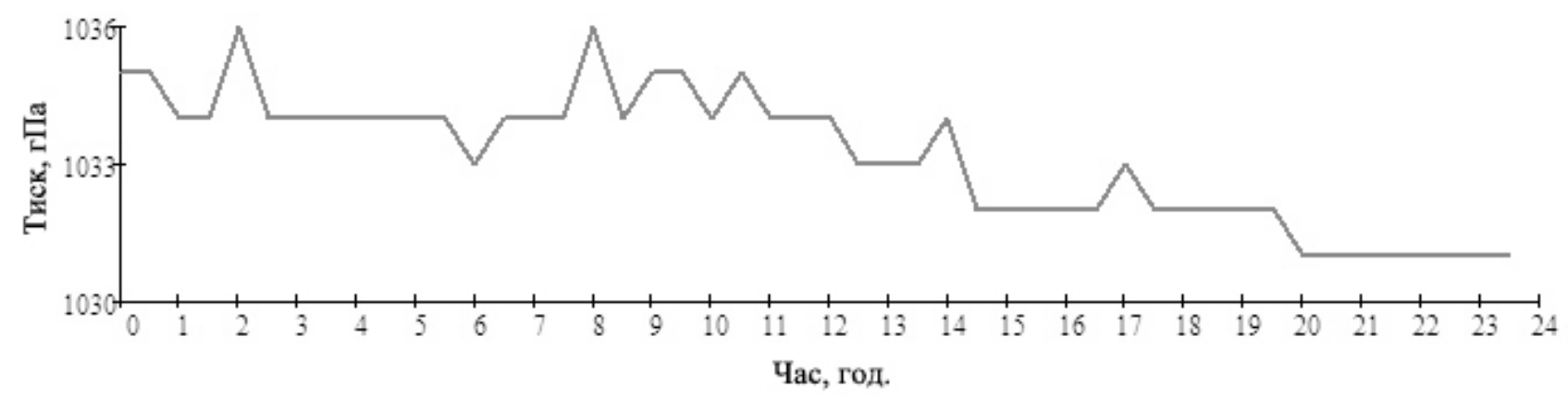

б)

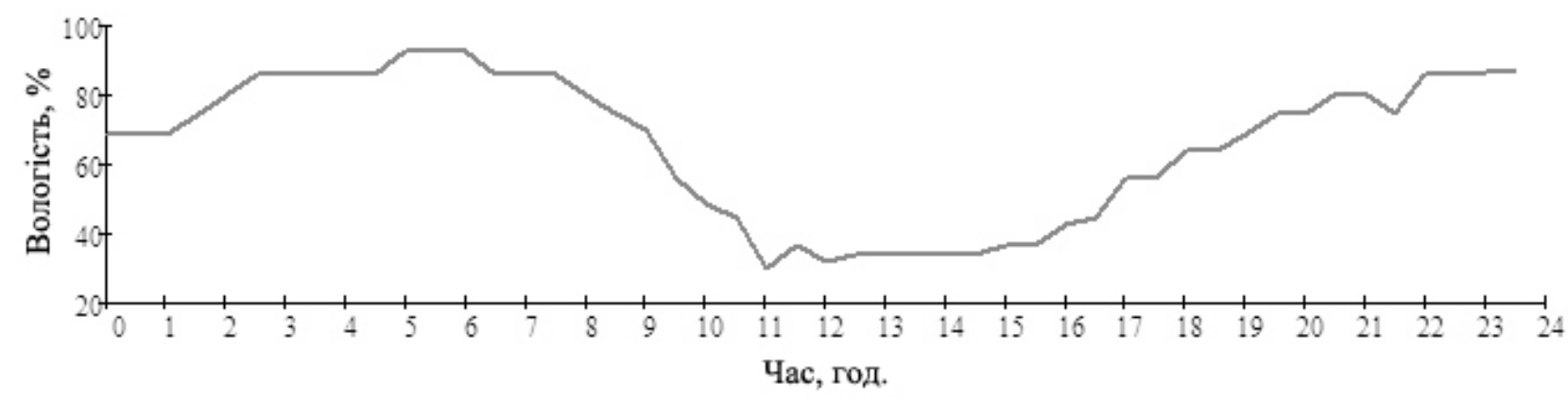

в)

Рис. 3. Залежність зміни основних метеорологічних характеристик від тривалості доби в Києві станом на 28 жовтня 2014 року: а) температури; б) тиску; в) вологості. 


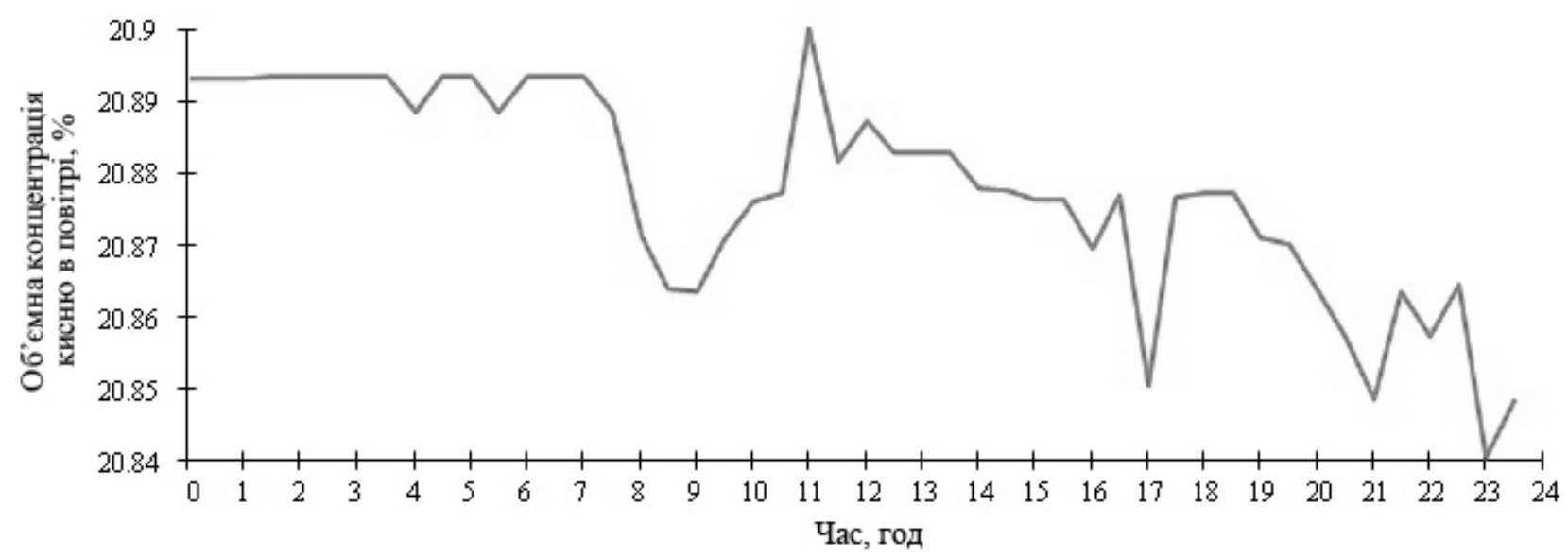

\section{Рис. 4. Зміна об'ємної концентрації кисню в повітрі в залежності від тривалості доби в Києві станом на 28 жсовня 2014 року.}

періодичності та погодних аномаліях (рис. 3, 4).

Аналітичне значення парціальної густини кисню $\left(E, \Gamma / \mathbf{m}^{3}\right)$ прямо пропорційне атмосферному тиску $(P$, гПа) за виключенням парціального тиску водяної пари (e, гПа) і обернено пропорційно температурі повітря $(T, K)(3)$ :

$E=0,2315 \cdot 10^{6} \cdot \frac{(P-e)}{R \cdot T}$,

де $R$ - питома газова стала для сухого повітря за тиску вираженого в гПа.

При цьому парціальний тиск водяної пари:

$e=\varphi \cdot p_{\text {нас }}$,

де $\varphi-$ вологість повітря, а $p_{\text {нас }}-$ обчислюється згідно рекомендацій Guide to Meteorological Instruments and Methods of Observation [6]:

$p_{\text {нас }}\left(P, T^{\prime}\right)=f(P) \cdot r\left(T^{\prime}\right) ;$

$f(P)=1,0016+3,15 \cdot 10^{-6} P-0,074 \cdot P^{-1} ;$

$r\left(T^{\prime}\right)=6,112 \cdot e^{\frac{17,62 T^{\prime}}{243,12+T^{\prime}}}$,

де $T$ - температура повітря в градусах Цельсія, ${ }^{\circ} \mathrm{C}$.

Перехід до об'ємної концентрації кисню проходив за наступним співвідношенням [7, с. 894]:

$\left[\mathrm{O}_{2}\right]=\frac{6,236 \cdot E \cdot T}{P^{\prime} \cdot M_{O_{2}}}$ де $P^{\prime}$ - атмосферний тиск в мм.рт.ст., $M_{\mathrm{O}_{2}}$ - молярна маса кисню.

Таким чином кінцевий аналітичний вигляд для розрахунку об'ємної концентрації кисню в повітрі має вигляд:

$\left[\mathrm{O}_{2}\right]\left(P, T^{\prime}, \varphi\right)=20,957 \cdot\left(1-\frac{e\left(P, T^{\prime}, \varphi\right)}{P}\right)$.

В рамках дослідження також проаналізовані зміни головних метеорологічних параметрів (температури, тиску, вологості) на протязі одного року (листопад 2013 р. - жовтень 2014) в м. Києві (рис. 5) та отримана сезонна зміна об'ємної концентрації кисню в повітрі на даній території (рис. 6).

В Інституті технічної теплофізики НАН України було проведено експериментальне дослідження роботи водогрійного котла із використанням газоаналізатору rbr-ECOM-KD. Результатами 11 вимірювань газоаналізатором 3 датчиком електрохімічного типу слугували значення коефіцієнту надлишку повітря $(\alpha)$, концентрації кисню $\left(\mathrm{O}_{2}\right)$, вуглекислого газу $\left(\mathrm{CO}_{2}\right)$, чадного газу (CO), монооксиду нітрогену (NO). Перед запуском котла газоаналізатором було проведено вимірювання характеристик повітря, що подається до топки; встановлено значення об'ємної концентрації кисню в повітрі на рівні 20,3% (при цьому допускається факт неповного очищення газоаналізуючих трактів).

В матеріалах, що описують залежність КНП, 


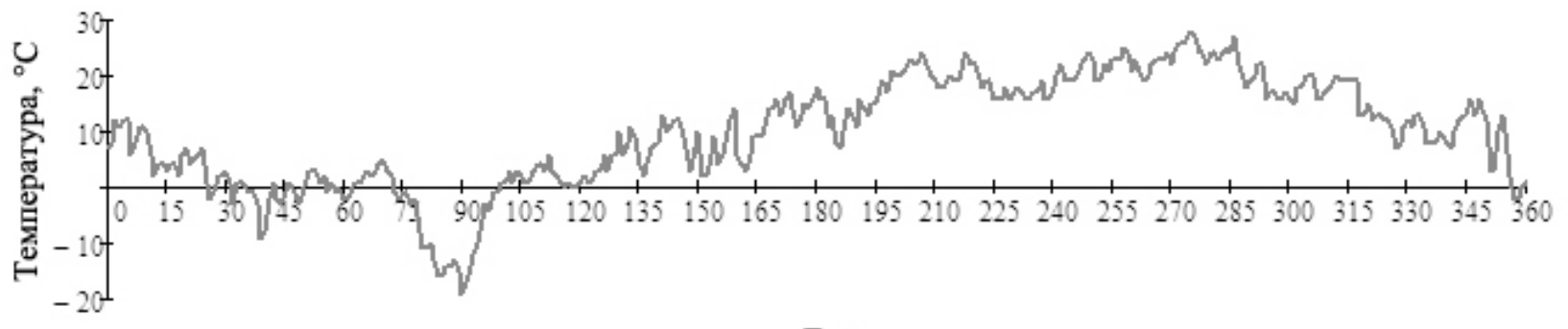

День

a)

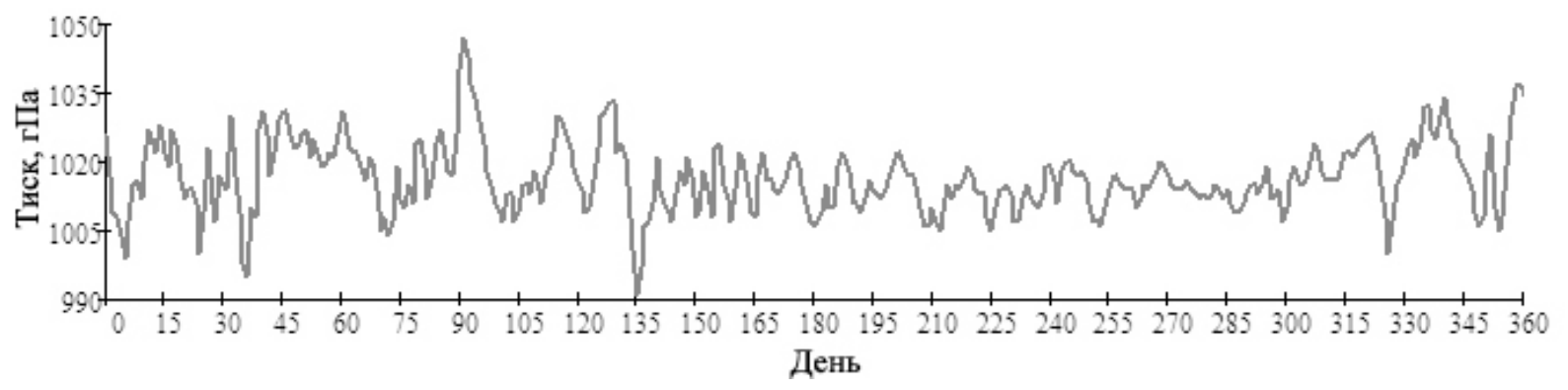

б)

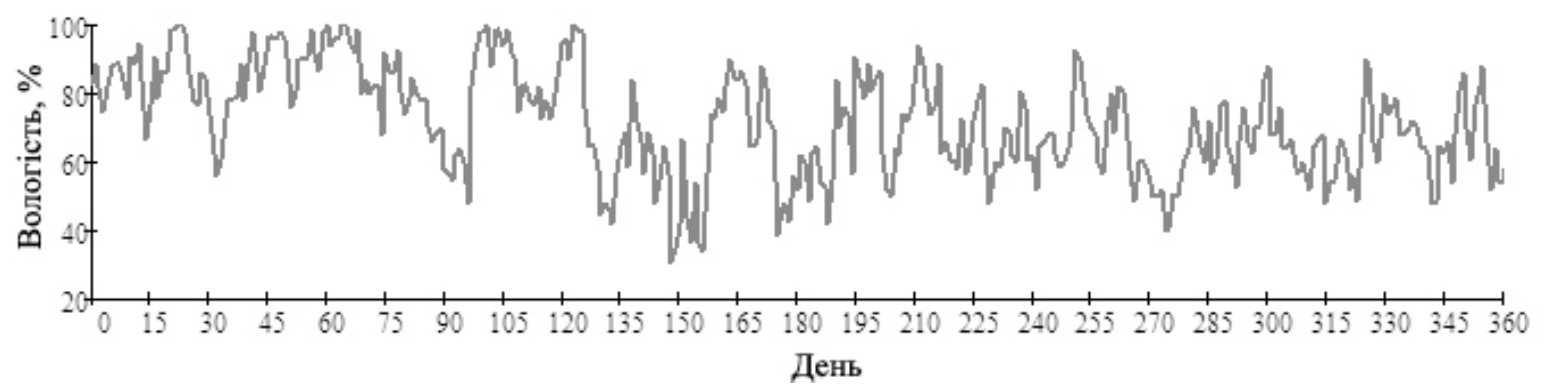

в)

Рис. 5. Залежсність зміни основних метеорологічних характеристик від пори роки в Києві станом на період листопад 2013 р. - жовтень 2014 р.: а) температури; б) тиску; в) вологості.

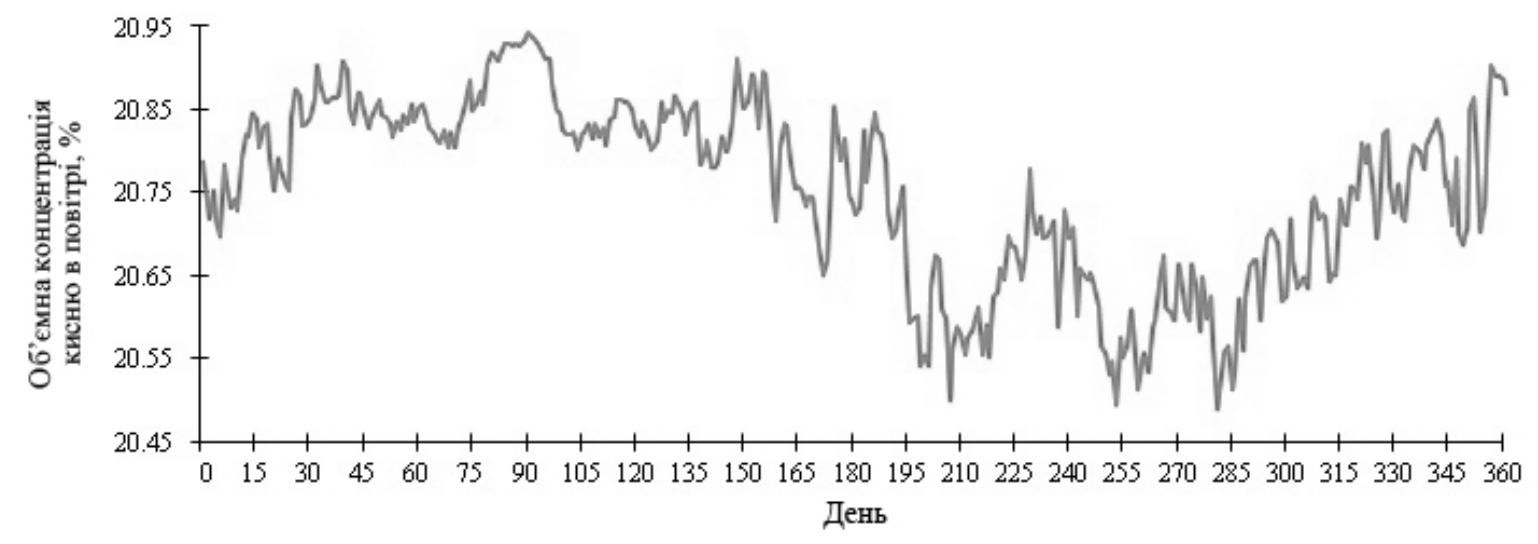

Рис. 6. Сезонна зміна об’ємної концентрації кисню в повітрі на території Києва в період з листопада 2013 р. - жсвтень 2014 р. 
та паспорті на газоаналізатор [8] за замовчуванням приймається значення об'ємної концентрації кисню в повітрі рівним 21,0 \% (1). Згідно 3 вищенаведеною інформацію про добову/сезону зміну значення концентрації кисню в повітрі, при розрахунку коефіцієнту надлишку повітря $\alpha$ маємо справу 3 невилученою складовою систематичної похибки, зумовленою використанням наближених значень. Далі, при визначені значення КНП, пропонується вводити поправки для компенсації похибки методу вимірювання.

На рис. 7 суцільною лінією представлено залежність концентрації кисню у відсотках від коефіцієнту надлишку повітря $\alpha$ за оберненою формулою (4), коефіцієнт кореляції - 0,997. Пунктирними лініями зображено довірчий інтервал. Розширена невизначеність складає 0,12 \% кисню (6). За паспортними даними на електрохімічний датчик, похибка визначення концентрації газів складає 5 \% виміряної величини (в нашому випадку це складає від 0,04 \% до 0,24 \% об’ємної концентрації кисню у вихідних газах). Точками позначені експериментальні дані, хрестиками - розрахункові значення КНП при концентрації кисню в повітрі 20,3%. Середньоквадратичне відхилення КНП, виданих газоаналізатором, від КНП за концентрації кисню в повітрі 20,3 \% склало 0,09.
$\left[\mathrm{O}_{2}\right]_{\text {sux }}(\alpha)=21 \cdot(\alpha-1) / \alpha$,

де $\left[\mathrm{O}_{2}\right]_{\text {вих }}(\alpha)$ - функція залежності об'ємної концентрації кисню у вихідних газах від КНП.

Для визначення довірчого інтервалу [9] спочатку оцінювалось стандартне відхилення $s$ виміряних значень від оберненої теоретичної залежності (3).

$s=\sqrt{\frac{1}{n-2} \cdot \sum_{i=0}^{n-1}\left(\left[O_{2}\right]_{B u x_{i}}-\left[O_{2}\right]_{B u x}\left(\alpha_{i}\right)\right)^{2}}$,

де $\left[\mathrm{O}_{2}\right]_{\text {вux }}$ - експериментально виміряні газоаналізатором значення об'ємної концентрації кисню, $\left[O_{2}\right]_{\text {вих }}\left(\alpha_{i}\right)$ - значення концентрації повітря у вихідних газах (\%) за формулою (3) при визначених газоаналізатором КНП, $n$ - кількість проведених вимірювань.

За отриманими значеннями СКВ похибки побудови градуювальної характеристики (ГХ) $S_{\left[\mathrm{O}_{2}\right]_{\text {eux }}}(\alpha)$ оцінювався довірчий інтервал випадкової похибки ГХ $\Delta\left(\left[\mathrm{O}_{2}\right]_{\text {вих }}\right)$ (розширена невизначеність $\left.U\left(\left[\mathrm{O}_{2}\right]_{\text {вих }}\right)\right)$ індивідуального значення $\left[\mathrm{O}_{2}\right]_{\text {вих }}$ :

$\Delta\left(\left[O_{2}\right]_{\text {вux }}\right)=U\left(\left[O_{2}\right]_{\text {sux }}\right)=t_{(1-\mathrm{P}) / 2}(v) \cdot S_{\left[\mathrm{O}_{2}\right]_{\text {gux }}}(\alpha)$,

де $t_{(1-\mathrm{P}) / 2}-$ квантиль розподілу Стьюдента, для довірчої імовірності $P=0,95$ та $v=n-2$ ступеней свободи.

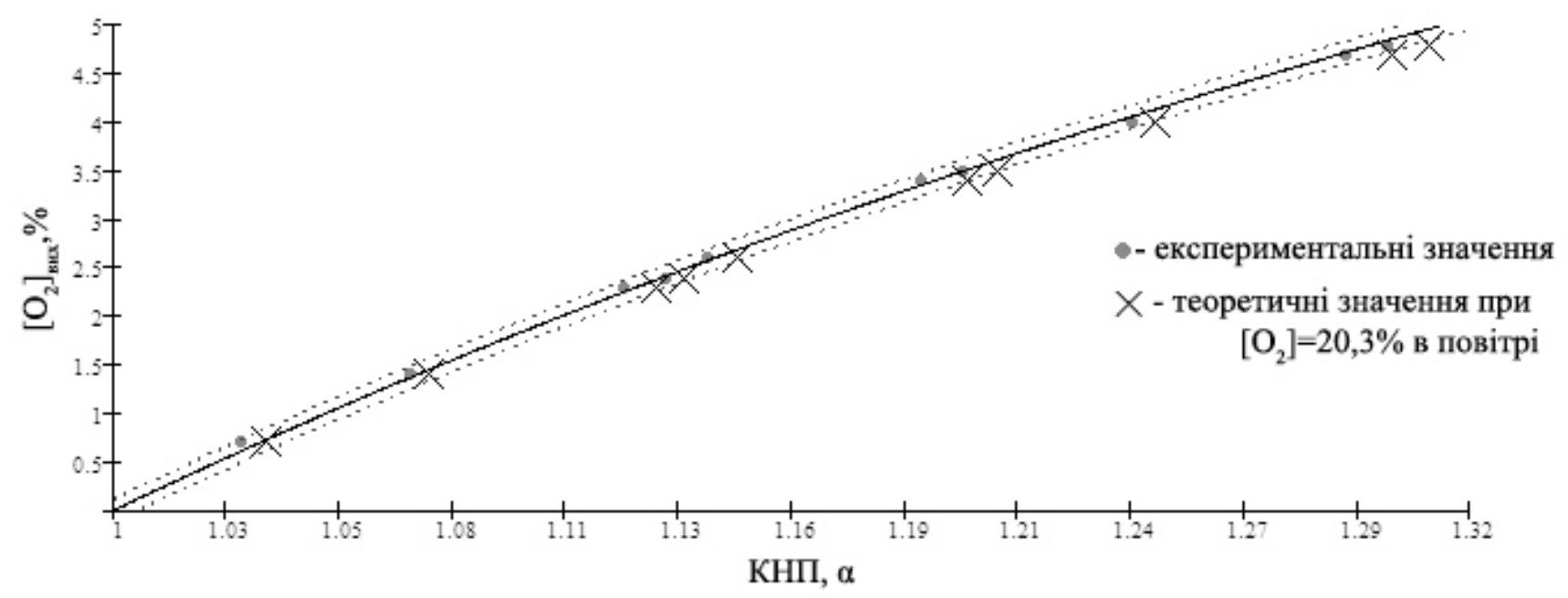

Рис. 7. Залежниість об’ємної концентрації кисню у вихідних газах від КНП із довірчими інтервалами (точками позначені експериментальні дані об'ємної концентрації кисню у вихідних газах, хрестиками - розраховані значення КНП за об'ємної концентрацї кисню в повітрі $20,3 \%$ ). 
Для побудови ГХ важливим є оптимальний вибір математичної моделі функції апроксимації [10]. Для визначення залежності значень концентрацій компонентів вихідних газів від КНП застосована поліноміальна нелінійна регресія (поліноми Чебишева) [11]. Було розраховано залежність об'ємної концентрації вуглекислого газу (7) з коефіцієнтом кореляції - 0,995 (рис. 8, а), масової концентрації чадного газу (8) 3 коефіцієнтом кореляції - 0,71 (рис. 8, б) та масової концентрації монооксиду нітрогену (9) 3 коефіцієнтом кореляції - 0,82 (рис. 8, в).

Статистична обробка даних проводилась в програмному пакеті MathCAD [12].

$\left[\mathrm{CO}_{2}\right]_{\text {вих }}(\alpha)=-1582+5583 \cdot \alpha-7269 \cdot \alpha^{2}+4181 \cdot \alpha^{3}-$ $-898,4$;

$[\mathrm{CO}]_{\text {вих }}(\alpha)=456632,9-1114000,4 \cdot \alpha+905420,4 \cdot \alpha^{2}-$

$-245044,4 \cdot \alpha^{3}$;

$[\mathrm{NO}]_{\text {вих }}(\alpha)=-1502,3+4249,1 \cdot \alpha-3776 \cdot \alpha^{2}+$

$+1099,2 \cdot \alpha^{3}$

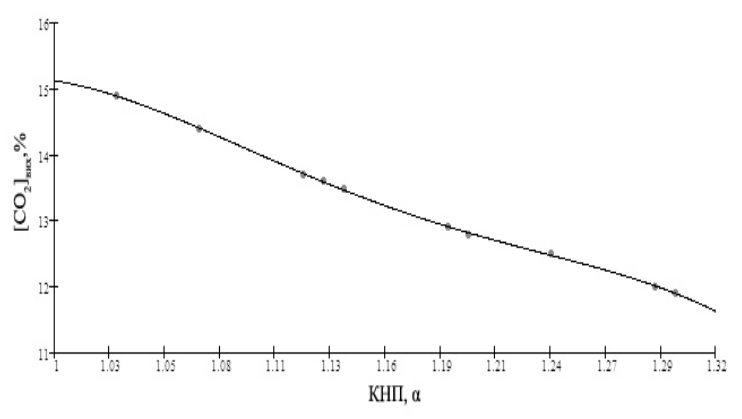

a)
Дані залежності та значення коефіцієнтів кореляції, показують, що за розрахунковими інтерполянтами, на основі обчисленого КНП, за об'ємною концентрацією кисню у вихідних газах та у повітрі, можна прогнозувати значення концентрацій компонентів вихідного газу. Звісно, розраховані рівняння за малого обсягу вимірювальної інформації, не дають достатньої точності. Тому даний підхід, для свого підтвердження, потребує планованого експерименту із більшою кількістю вимірювань 3 багатократними спостереженнями.

Беручи до уваги наведені вище дані про концентрацію кисню в повітрі, актуальним є завдання врахування добової/сезонної зміни кліматичних параметрів середовища та умов експлуатації при проведенні контролю процесу горіння. Тому, ми рекомендуємо враховувати поправку на поточне значення об'ємної концентрації кисню в повітрі шляхом введення зворотнього зв'язку в блок обчислення КНП газоаналізатору. На рис. 9 відображено двохпараметричну залежність поправки (абсолютної мето-

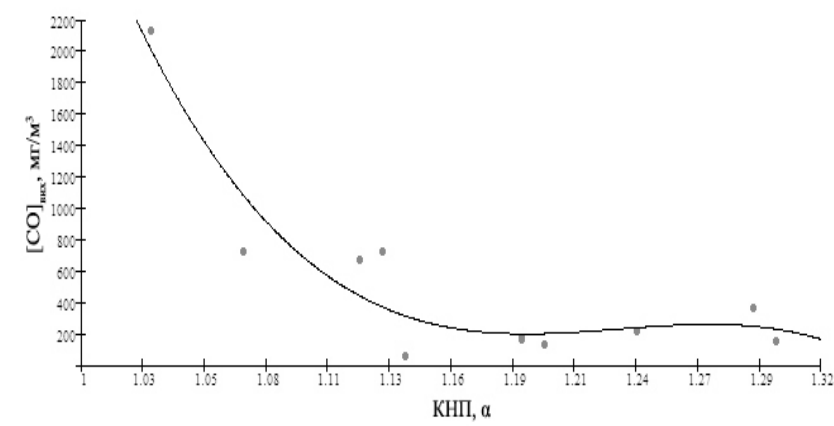

б)

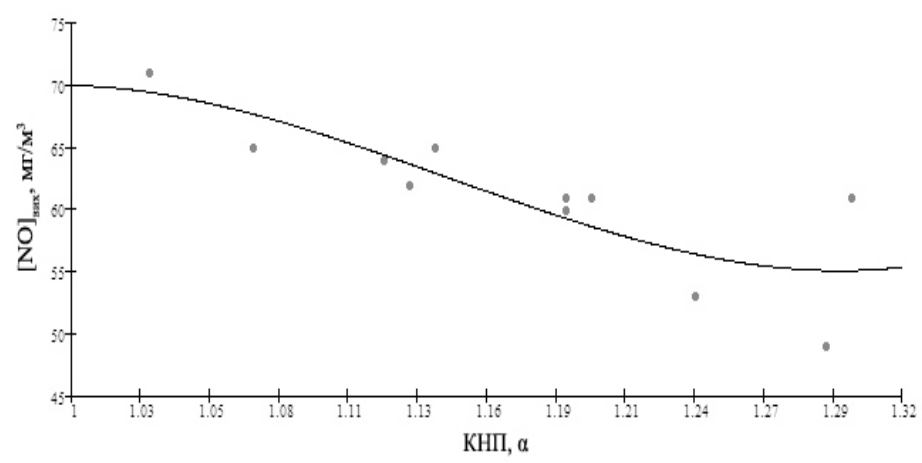

в)

Рис. 8. Залежності концентрацій компонентів продуктів горіння від КНП: а-вуглекислий газ; б-чадний газ; в-монооксид нітрогену. 


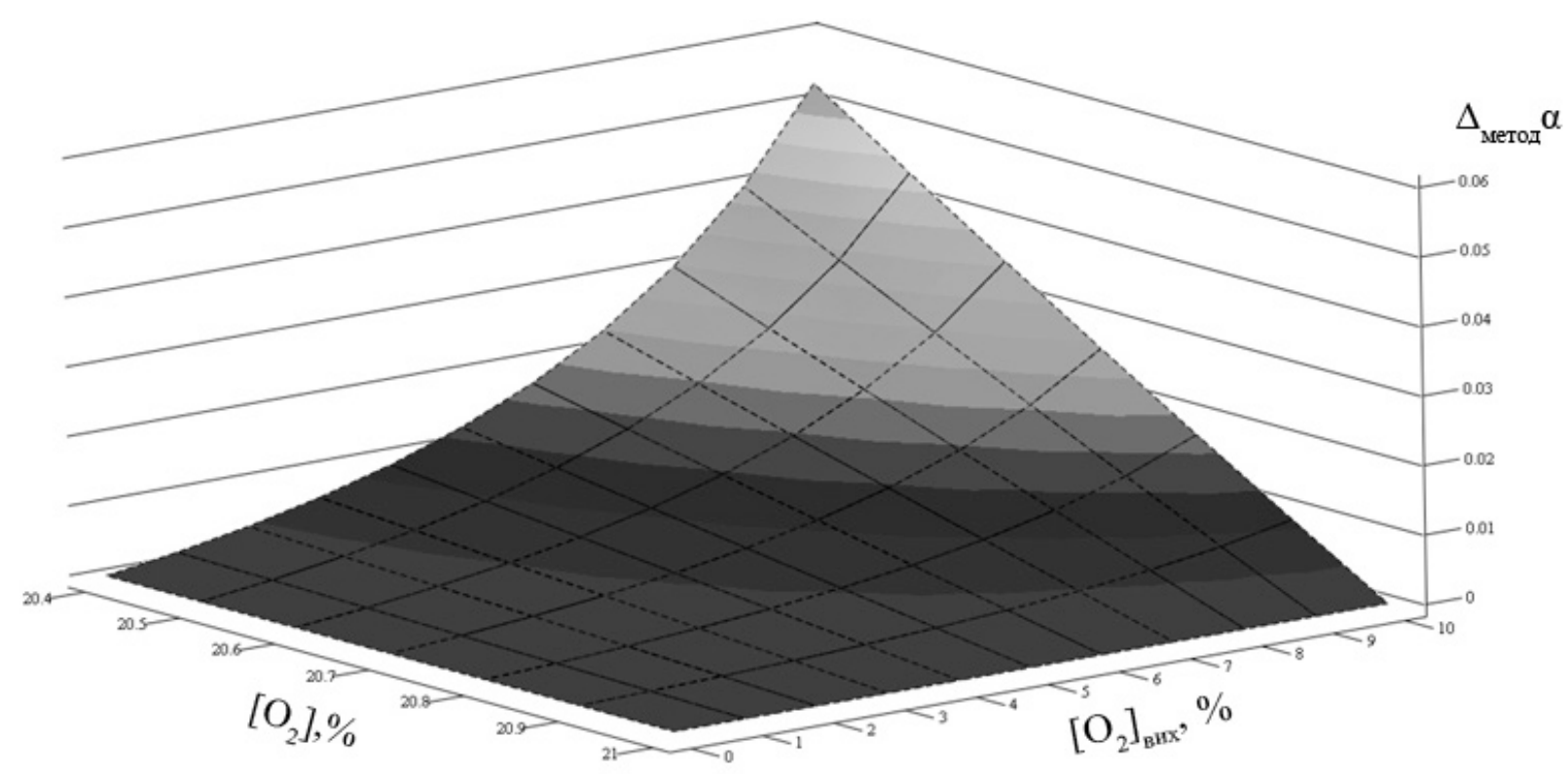

\section{Рис. 9. Двохпараметрична залежність поправки (абсолютної методичної похибки визначення КНП) від об’ємної концентрації кисню в повітрі та об'ємної концентрації кисню у вихідих газах.}

дичної похибки визначення КНП) від іï аргументів, яка обчислюється наступним чином:

$\Delta_{\text {метод }} \alpha\left(\left[O_{2}\right],\left[O_{2}\right]_{\text {gux }}\right)=\frac{\left[O_{2}\right]_{\text {вux }} \cdot\left(21-\left[O_{2}\right]\right)}{\left(\left[O_{2}\right]-\left[O_{2}\right]_{\text {gux }}\right) \cdot\left(21-\left[O_{2}\right]_{\text {gux }}\right)}$.

В роботі [13] було запропоновано формулу розрахунку КНП на основі коефіцієнтів балансу наближеної до реальної реакції горіння палива:

$$
\alpha=\frac{n}{x+y / 4-z / 2},
$$

де параметри $n, x, y$ та $z$ визначаються $з$ рівняння ідеальної реакції горіння:

$\mathrm{C}_{x} \mathrm{H}_{y} \mathrm{O}_{z}+\left(x+\frac{y}{4}-\frac{z}{2}\right) \cdot \mathrm{O}_{2} \rightarrow x \cdot \mathrm{CO}_{2}+\frac{y}{2} \cdot \mathrm{H}_{2} \mathrm{O}$.

Однак реальна реакція горіння містить набагато більше складових, що обумовлено характерним складом повітря та палива:

$\mathrm{C}_{x} \mathrm{H}_{y} \mathrm{O}_{z}+n \cdot\left(\mathrm{O}_{2}+\mathrm{A} \cdot \mathrm{N}_{2}+\mathrm{B} \cdot \mathrm{CO}_{2}+\mathrm{C} \cdot \mathrm{H}_{a b s} \cdot \mathrm{H}_{2} \mathrm{O}\right) \rightarrow$

$\rightarrow \alpha \cdot \mathrm{CO}_{2}+b \cdot \mathrm{CO}+c \cdot \mathrm{H}_{2}+d \cdot \mathrm{H}_{2} \mathrm{O}+e \cdot \mathrm{O}_{2}+f \cdot \mathrm{NO}_{x}+$

$+h \cdot C_{x^{\prime}} H_{y^{\prime}} O_{z^{\prime}}$,

де $A, B, C$ - відповідні концентрації азоту, вуглекислого газу та води; $a, b, c, d, e, f, h$ - коефіцієнти врівноваження вихідних сполук.
В подальших дослідженнях методів підвищення точності визначення КНП та концентрацій компонентів вихідного газу планується описати коефіцієнти балансу реакції горіння вуглеводних речовин. При наявності інформації про якісний та кількісний склад палива і повітря, коефіцієнтів рівняння реакції горіння, створюються умови для планового експерименту, метою якого є створення математичної моделі оптимального режиму експлуатації котлоагрегатів.

\section{Висновки}

Споживання паливно-енергетичних ресурсів на промислових підприємствах та в сфері ЖКГ становить істотну частку собівартості виробленої продукції, тому в даний час актуальним $\epsilon$ використання вторинних енергетичних ресурсів (ВЕР). В якості ВЕР металургійного виробництва можуть виступати доменний, коксовий газ та інші види ресурсів. В якості ВЕР ЖКГ - тверде паливо, генераторний газ та ін. Утилізація ВЕР дає значний енергозберігаючий ефект, оскільки дозволяє економити використання основного палива - природного газу.

Проблема економії паливних ресурсів на сьогоднішній день є актуальною не тільки для України, а й всього світу, тому контроль за процесами горіння в котлоагрегатах має бути мак- 
симально точним. Запропонований метод підвищення точності вимірювання КНП в котлоагрегатах із застосуванням газоаналізаторів електрохімічного типу має надзвичайну перспективність, оскільки враховує методичну похибку вимірювання, що закладена в електронну систему обчислення пристроїв. Для визначення КНП газоаналізатору необхідно визначити поточну об'ємну концентрацію кисню в димових газах та порівняти іiі зі значенням об'ємної концентрації кисню в повітрі, яка вважається рівною $21 \%$ (1). Однак даний параметр не є константою, і залежить не тільки від висоти розташування об'єкта контролю, але й від таких параметрів як вологість і температура повітря, та атмосферний тиск.

Кінцева формула для визначення КНП з врахуванням поточної концентрації кисню в повітрі має вигляд:

$$
\alpha=1+\frac{\left[\mathrm{O}_{2}\right]_{\text {вux }}}{\left[\mathrm{O}_{2}\right]-\left[\mathrm{O}_{2}\right]_{\text {вux }}} \text {. }
$$

Таким чином, введення зворотнього зв'язку в систему газоаналізатора по визначенню поточної об’ємної концентрації кисню в повітрі дозволить підвищити точність вимірювання КНП (до 5 \%).

\section{ЛІТЕРАТУРА}

1. Кучерук В.Ю. Огляд методів контролю складу димових газів котельних установок / В.Ю. Кучерук, I.A. Дудатьев // Збірник наукових праць ОДАТРЯ. - 2013. - №1. - С. 51 - 55.

2. Воликов А.Н. Повышение эффективности сжигания топлива в котлоагрегах / А.Н. Воликов, О.Н. Новиков, А.Н. Окатьев // Энергонадзор-информ. - 2010. - №1. - С. $54-57$.

3. Ночвай B.M. Метод контролю витрат кисню пальників по потоку випромінювання полум'я при спалюванні пропан-бутану / В.М. Ночвай // Вісник ЖДТУ. - 2012. - №2. - С. 48 - 52.

4. Скоробогатова И.В. Пути повышения эффективности использования топлива при реше- нии задач автоматического управления / И.В. Скоробогатова, С.В. Неежмаков, Б.В. Гавриленко // Наукові праці ДонНТУ. - 2011. - №21(183). C. $48-54$.

5. Методика расчета количества кислорода в атмосферном воздухе на основе метеорологических параметров с целью прогнозирования метеопатических эффектов атмосферы [Текст]: (метод. рекомендации) / Гл. упр. лечеб.-профилакт. помощи; сост. В. Ф. Овчарова. - М.: МЗ CCCP. - 1983. - 13 c.

6. Guide to Meteorological Instruments and Methods of Observation / World Meteorological Organization, 2008. - №8.- 119 p.

7. Новый справочник химика и технолога. Аналитическая химия. Ч.1. - С.-Пб.: АНО НПО «Мир и Семья», 2002. - 964 с.

8. Bedienungsanleitung ECOM $\AA$ KD. Kreative Technikausdem Hauserbr. - rbr Messtechnik GmbH, 2007 - P. $41-43$.

9. Игуменцева Н.В. Статистический анализ результатов эксперимента и наблюдений / Н.В. Игуменцева, В.И. Пахомов. - Харьков: ООО “Компания Смит", 2005 г. - С. 129 - 138.

10. Рекомендация по метрологии. Градуировочные характеристики средств измерений. Методы построения. Оценивание погрешностей. МИ 2175-91. - С-Пб.: ВНИИМ им. Д.И. Менделеева, 1997 - С. 3 - 15.

11. Кобзарь А.И. Прикладная математическая статистика (для инженерных и научных работников) /А.И. Кобзарь // М.: ФИЗМАТЛИТ, 2006. - C. $681-691$.

12. Плис А.И. MathCad: Практический практикум для экономистов и инженеров / А.И. Плис, Н.А. Сливина. - М.: Финансы и статистика, 1999.- C. $538-548$.

13. William M. Silvis. The Algorithmic Structure of the Air/Fuel Ratio Calculation / Silvis M. William // Readout. - 1997. - №15. - P. 17 - 24. 


\section{INCREASING THE ACCURACY OF MEASURING THE AIR EXCESS COEFFICIENT IN THE BOILERS USING THE ELECTROCHEMICAL GAS ANALYZER}

\author{
Babak V.P. ${ }^{1}$, Zaporozhets A.O. ${ }^{1}$, Redko O.O. ${ }^{2}$
}

${ }^{1}$ Institute of Engineering Thermophysics NAN of Ukraine, Zhelyabov str., 2a, Kiev. 03680, Ukraine

${ }^{2}$ National Aviation University, Komarov Ave., 1, Kiev, 03680, Ukraine

In this article the features of definition an air excess coefficient in boilers are investigated. The objective of the work is consider the exciting methods and typical gas analyzers for monitoring the flue gas composition and propose the method to improve the accuracy of measuring the air excess coefficient. Analyzed and generated the classification of exciting methods for monitoring gaseous substances in the flue gases. Comparative characterization of electrochemical analytical methods and modern portable gas analyzers are showed. Described the advantages of conductometric and polarographic techniques of physicochemical analytical methods. Considered the dependence of oxygen partial density changing from the main meteorological characteristics - temperature, humidity and atmospheric pressure. Set the seasonal changes of oxygen volume concentration in the air (Kiev, Ukraine) based on experimental data. Considered the traditional method of calculating the air excess coefficient in the gas analyzer and suggested the way to improve its accuracy based on the current value of the oxygen concentration in the air. Submitted 2-parametric correction dependence (absolute error measurement method) of air excess coefficient from oxygen partial density in the air and oxygen concentration in the initial gas of combustion process. Based on the experimental results proposed to use the component concentration of exhaust gases as additional information parameters for the calculation of air excess coefficient.

References 13, tables 3, figures 9.

Key words: excess air ratio, gas analyzers, flue gases, control, optimization, measurement, boilers.

1. Kucheruk V.Ju. Review of methods of controlling the composition of flue gas boiler installations / V.Ju. Kucheruk, I.A. Dudat'ev // Scientific Papers of ODATRJa. - 2013. - №1. - P. 51 - 55. (Ukr.)

2. Volikov A.N. Improving the efficiency of fuel combustion in boilers / A.N. Volikov, O.N. Novikov, A.N. Okat'ev // Jenergonadzor-inform. 2010. - №1. - P. 54 - 57. (Rus.)

3. Nochvaj V.M. The method of consumption monitoring oxygen flow to the burner flame radiation by burning propane-butane / V.M. Nochvaj // Bulletin of ZhDTU. - 2012. - №2. - P. 48 - 52. (Ukr.)

4. Skorobogatova I.V. The way improve fuel efficiency in solving the problems of automatic control / I.V. Skorobogatova, S. V. Neezhmakov, B.V. Gavrilenko // Scientific Papers of DonNTU. - 2011. - №21(183). - P. 48 - 54.

5. Method of calculating the amount of oxygen in the atmosphere based on meteorological parameters in order to predict the meteopathic effects of the atmosphere [Text]: (method. recommendations) / General Directorate of therapeutic and prev. care; comp. V. F. Ovcharova. - M.: MZ USSR. - 1983. 13 p. (Rus.)

6. Guide to Meteorological Instruments and Methods of Observation / World Meteorological Organization, 2008. - №8.- 119 p.

7. The new directory chemist and technologist. Analytical chemistry. Ch.1. - S.-Pb.: ANO NPO «World and Family», 2002. - 964 p.

8. Bedienungsanleitung ECOM ${ }^{\circledR}$ KD. Kreative Technikausdem Hauserbr. - rbrMesstechnik GmbH, 2007 - P. $41-43$.

9. Igumenceva N.V. Statistical analysis of the experimental results and observations / N.V. Igumenceva, V. I. Pahomov. - Har'kov: OOO "Company Smit", 2005 g. - P. 129 - 138 (Rus.)

10. Recommendation for metrology. Calibration characteristics of measuring instruments. Methods of construction. estimation errors. MI 2175-91. - S-Pb.: VNIIM im. D.I. Mendeleeva, 1997 - P. 3 15. (Rus.)

11. Kobzar' A.I. Applied mathematical statistics (for engineers and scientists) /A.I. Kobzar' // M.: FIZMATLIT, 2006. - P. 681 - 691. (Rus.)

12. Plis A.I. MathCad: Practical workshop for economists and engineers / A.I. Plis, N.A. Slivina. - M.: Finance and Statistics,1999.- P. 538 - 548. (Rus.)

13. William M. Silvis. The Algorithmic Structure of the Air/Fuel Ratio Calculation / Silvis M. William // Readout. - 1997. - №15. - P. 17 - 24.

Получено 17.12.2014 Received 17.12.2014 